\title{
Role of interleukin-32 in cancer biology (Review)
}

\author{
HAIMENG YAN ${ }^{1}$, DONGHUA HE $^{1}$, XI HUANG $^{1}$, ENFAN ZHANG $^{1}$, QINGXIAO CHEN $^{1}$, \\ RUYI XU ${ }^{1}$, XINLING LIU ${ }^{1}$, FUMING $\mathrm{ZI}^{2}$ and ZHEN CAI ${ }^{1}$ \\ ${ }^{1}$ Bone Marrow Transplantation Centre, The First Affiliated Hospital, School of Medicine, Zhejiang University, Hangzhou, \\ Zhejiang 310006; ${ }^{2}$ Department of Haematology, The Second Affiliated Hospital of Nanchang University, \\ Nanchang, Jiangxi 330001, P.R. China
}

Received February 23, 2018; Accepted April 30, 2018

DOI: $10.3892 / \mathrm{ol} .2018 .8649$

\begin{abstract}
Interleukin-32 (IL-32), a novel proinflammatory cytokine, is highly expressed in various cancer tissues and in established cancer cell lines. IL-32 has been revealed to serve a crucial role in human cancer development, including tumour initiation, proliferation and maintenance. The expression of IL-32 is regulated by numerous factors, including genetic variations, hypoxia and acidosis in the tumour microenvironment. Understanding the underlying mechanisms of IL-32 expression and its function are critical for the discovery of novel therapeutic strategies that target IL-32. This is a review of the current literature on the regulation and function of IL-32 in cancer progression, focusing on the molecular pathways linking IL-32 and tumour development.
\end{abstract}

\section{Contents}

1. Introduction

2. IL-32 expression in cancer

3. The role of IL-32 in cancer

4. The mechanisms of IL-32 in cancer

5. The regulation of IL-32 in cancer

6. Conclusion and future directions

\section{Introduction}

Inflammation serves a pivotal role in carcinogenesis and the promotion, malignant conversion and migration of malignant tumours (1). It has been established that inflammatory conditions in certain organs increase the risk of cancer. Tumour-associated inflammation also enables cancer

Correspondence to: Professor Zhen Cai, Bone Marrow Transplantation Centre, The First Affiliated Hospital, School of Medicine, Zhejiang University, 79 Qingchun Road, Hangzhou, Zhejiang 310006, P.R. China

E-mail: caiz@zju.edu.cn

Key words: interleukin-32, cancer, mechanisms, regulation cells to escape from the surveillance of adaptive immunity and diminishes the cellular response to chemotherapeutic drugs (2). Therefore, inflammation is considered a hallmark of cancer (2,3). Studies have revealed the molecular and cellular pathways that are vital for linking inflammation and cancer (1). The effect of immune cells on tumour cells partly depends on the production of cytokines, chemokines, growth factors and reactive oxygen species. Pro- and anti-tumorigenic effects are exerted by tumour-associated cytokines; interleukin (IL)-1, IL-6 and IL-8 have been revealed to promote carcinogenesis and tumour growth and invasion (4-6). By contrast, IL-10 and IL-27 induce apoptosis in cancer cells and prevent the development of cancer $(7,8)$. The pro-inflammatory cytokine IL-32 has also been implicated in the development of various types of cancer, including hepatocellular carcinoma, pancreatic cancer, oesophageal cancer, lung cancer, gastric cancer, colon cancer, breast cancer and cutaneous T-cell lymphoma (9-16).

IL-32 was first identified as natural killer cell transcript 4 (NK4) as it was detected in activated natural killer cells and T cells (17). The biological function of IL-32 remained unknown until 2005 when Kim et al (18) demonstrated for the first time that recombinant NK4 could induce several pro-inflammatory cytokines, including tumour necrosis factor (TNF)- $\alpha$ and IL-8 (18). IL-32 is located at human chromosome 16p13.3 and contains eight small exons. According to the GenBank Database, IL-32 has more than nine isoforms, which are transformed into four major splice variants: IL-32 $\alpha$, IL-32 $\beta$, IL-32 $\gamma$ and IL-32 $\delta$ (19). Among the variants, IL-32 $\beta$ appears the most abundant and IL $32 \gamma$ is the most broadly studied $(20,21)$. Furthermore, IL-32 $\gamma$ can be spliced into IL-32 $\beta$ in vitro and in vivo. The overexpression of splice-resistant IL-32 $\gamma$ in THP1 cells or rheumatoid arthritis (RA) synovial fibroblasts revealed a greater induction of IL-6 and C-X-C motif chemokine ligand 8 than in the same models overexpressing IL-32 $\beta$ (22). In addition to inducing cytokine production, the transient overexpression of endogenous IL-32 $\beta$ or IL-32 $\gamma$ resulted in cell death, whereas IL-32 $\alpha$ overexpression failed to induce cell death (23). Notably, restoring the IL-8 survival-signalling pathway by co-overexpressing $\mathrm{C}-\mathrm{X}-\mathrm{C}$ motif chemokine receptor 1 with IL-32 $\beta$ or IL-32 $\gamma$ in 293 cells prevented IL-32 $\beta$ but not IL-32 $\gamma$ from inducing cell death (23). These studies indicated functional differences between these diverse splice variants. The biological properties of each isoform have been described in several reports (24-26). IL-32 $\alpha$ increases IL-6 
expression in THP-1 promonocytic cells (27). This result was also supported by a report that revealed that IL-32 $\alpha$ induced IL-6 production by inhibiting B-cell lymphoma 6 (28). However, IL-32 $\theta$-expressing THP-1 cells revealed a reduced expression of C-C motif chemokine ligand 5 (29). These studies suggested that IL-32 functions as an intracellular mediator of inflammation. Additionally, numerous studies have provided evidence that IL-32 has diverse functions due to the intracellular interactions of its isoforms $(26,30)$.

IL-32 $\gamma$, originally known as NK4, was anticipated to be a secreted protein because it contains a signal peptide sequence and lacks a transmembrane region (18). Kim et al (18) demonstrated that induced the overexpression of either IL-32 $\alpha$ or IL-32 $\beta$ resulted in the secretion of their proteins and stimulated peripheral blood mononuclear cells (PBMCs), NK cells and A549 cells to release IL-32. Another study revealed that IL-32 was secreted from T cells undergoing apoptosis (20). By contrast, Heinhuis et al (22) reported that the overexpression of spliced or splice-resistant IL-32 $\gamma$ led to the secretion of IL-32 but did not result in the release of intracellular lactate dehydrogenase (22). Taken together, these results suggested that endogenous IL-32 can be secreted via non-classical and classical secretory pathways (31). A definitive receptor has not been discovered for IL-32, but proteinase 3 has been recently recognized as a specific IL-32 binding protein (32). Furthermore, IL-32 can bind the extracellular domain of integrins, which might act as receptors through the focal adhesion kinase 1 (FAK-1) signalling pathway (33). As an extracellular protein, IL-32 has been revealed to serve a crucial role in the process of monocyte differentiation into macrophage-like cells with phagocytic capacities (34). More recently, IL-32 was reported to promote monocyte differentiation into CD1c+ dendritic cells and CD163+CD68+ macrophages (35). Therefore, IL-32 not only induces the production of pro-inflammatory cytokines but also directly affects the development and maturation of specific immune cells. IL-32 is also involved in numerous inflammatory and infectious diseases, including rheumatoid arthritis, chronic obstructive pulmonary disease, mycobacterium tuberculosis infections and inflammatory bowel disease (36-39).

\section{IL-32 expression in cancer}

A number of studies on a diverse range of tumour types have investigated the clinical significance of IL-32 expression as a prognostic factor. A higher expression of IL-32 in cancerous tissues of the human liver, pancreas, oesophagus, lung and stomach has been revealed in comparison with the expression in normal tissue or serum (Table I) $(9-11,13,40)$. The expression of IL-32 $\alpha$ was upregulated in tissues and serum from patients with hepatocellular carcinoma (HCC) (9). Additionally, surgical tissues from patients with pancreatic cancer revealed significantly higher expression levels of IL-32 compared with that of healthy pancreatic or normal tissues (10). Immunohistochemical studies of oesophageal cancer tissues have revealed that oesophageal cancer cells stain positively for IL-32, whereas normal oesophageal cells display minimal staining (11). In human lung cancer, Sorrentino and Sorrentino et al (40) reported that high IL-32 expression was present in adenocarcinoma (AC), large-cell carcinoma and small cell lung cancer but not in squamous-cell carcinoma (SCC). Notably, in the present study, IL-32 expression was associated with a poor clinical outcome. These results are in line with those of a study that revealed that IL-32 is associated with tumour cell invasion and metastasis in primary lung adenocarcinoma (12). Furthermore, the positive correlation between IL-32 and cancer invasion that was demonstrated in lung cancer was also reported in gastric and breast cancer $(13,15)$. Tsai et al (13) demonstrated that the overexpression of IL-32 in gastric cancer appeared to correlate with the aggressiveness of cancer and a poor prognosis. In a study that involved breast cancer, a positive link was demonstrated between IL-32 expression and tumour size, the number of lymph node metastases and tumour stage (15). However, there remains controversy regarding the expression and action of IL-32 in tumours. A recent report noted that, although cervical cancer tissues expressed a higher level of IL-32, the expression of IL-32 was not correlated with patient mortality (41). In chronic myelomonocytic leukaemia, IL-32 expression was lower than in healthy donors. Furthermore, IL-32 expression in stromal cells from the bone marrow of patients with leukaemia served an important role in inducing apoptosis in leukaemia cells (42).

In these studies, IL-32 served either an oncogenic or a tumour suppressive role, likely due to disparities in the predominant IL-32 isoform expressed in the tumour tissue. Genetic variations among different ethnic groups and the different clinical stages of tumours may also contribute to these contradictory results. The expression of IL-32 may be a valuable independent prognostic tumour marker for overall survival rates and the degree of metastasis in patients with various forms of cancer.

\section{The role of IL-32 in cancer}

The mitogenic properties of IL-32. IL-32 has been demonstrated to be involved in cancer development. A recent report noted that IL-32 can act as an important growth factor for human cutaneous T-cell lymphoma (CTCL) cells (16). The study revealed that IL-32 accelerated the proliferation of CTCL cell lines in a dose-dependent manner. Furthermore, the exposure of certain CTCL cell lines to anti-IL-32 antibodies in culture inhibited cell proliferation. These results indicated that IL-32 may be involved in the pathogenesis of CTCL as an autocrine growth factor. Similarly, extracellular IL-32 has also been proposed to act as a mitogenic factor in breast cancer (43). Our group recently revealed that IL-32 promoted multiple myeloma cell growth through inducing the production of IL- 6 in bone marrow stromal cells (44). Intracellular IL-32 also affects tumour growth. In hepatocellular carcinoma cells transfected with IL-32 small interfering RNA (siRNA), intrinsic apoptosis was increased and cell growth was decreased compared with the level of these activities in the control siRNA-transfected cells (9). These results are consistent with those of one previous study demonstrating that IL-32 suppression abated anti-apoptotic protein expression in pancreatic cancer cells (10).

Contrary to the oncogenic role of IL-32 in cancer cell proliferation and death, a number of reports have demonstrated that IL-32 inhibits the proliferation of several types of cancer, 
Table I. Expression of IL-32 in human tumour tissues.

\begin{tabular}{|c|c|c|c|}
\hline Tumour & Methods & IL-32 expression and prognosis & (Refs.) \\
\hline Hepatocellular carcinoma & $\begin{array}{l}\text { DNA microarray chips, RT-PCR, } \\
\text { IHC, WB }\end{array}$ & Higher in tumour tissues than in normal tissues & (9) \\
\hline Pancreatic cancer & RT-PCR, IHC & $\begin{array}{l}\text { Higher in tumour tissues than in pancreatic } \\
\text { or normal tissues }\end{array}$ & $(10)$ \\
\hline Oesophageal cancer & $\begin{array}{l}\text { RT-PCR, IHC } \\
\text { WB, ELISA }\end{array}$ & $\begin{array}{l}\text { Higher in tumour tissues and patients' serum than in } \\
\text { normal subjects }\end{array}$ & $(11)$ \\
\hline Lung cancer & $\begin{array}{l}\text { RT-PCR, IHC } \\
\text { LCM }\end{array}$ & $\begin{array}{l}\text { High in tumour tissues with a histology-specific } \\
\text { association; correlation with worse prognosis revealed }\end{array}$ & $(40)$ \\
\hline Gastric cancer & RT-PCR, IHC & $\begin{array}{l}\text { Higher in gastric carcinomas than in corresponding } \\
\text { normal mucosa; correlates with tumour progression } \\
\text { and poor prognosis }\end{array}$ & (13) \\
\hline Breast cancer & RT-PCR, IHC & $\begin{array}{l}\text { Higher in tumour tissues than in normal tissues; } \\
\text { correlates with tumour size, number of lymph } \\
\text { node metastases and tumour stage }\end{array}$ & $(15)$ \\
\hline \multirow[t]{2}{*}{ Cutaneous T-cell lymphoma } & RT-PCR, IHC & $\begin{array}{l}\text { Higher in tumour tissues than in normal tissues; } \\
\text { correlated with CCL17 and CCL18 expression }\end{array}$ & $(16)$ \\
\hline & ELISA & Correlated with disease activity & \\
\hline
\end{tabular}

RT-qPCR, reverse transcription-quantitative polymerase chain reaction; IHC, immunohistochemistry; WB, western blot analysis; LCM, laser capture microdissection.

including colon cancer, prostate cancer and melanoma $(45,46)$. Induction of IL-32 expression inhibited the growth of colon cancer cells, while suppression of endogenous IL-32 was reported to reverse this inhibitory effect. This observation was also reproduced in prostate cancer and melanoma cells $(45,46)$.

In addition to its role in tumour proliferation, IL-32 has also been linked to antitumour activities that are dependent on the influence of other cytokines and immune cells. Chronic myeloid leukaemia cell lines that overexpressed IL-32, upregulated the expression of Fas and UL16-binding protein 2 (47). In accordance with the results of the present study, Park et al (48) indicated that enforced overexpression of IL-32 in colon cancer cells potentiated the inhibitory effect of TNF- $\alpha$ and promoted the apoptosis of colon cancer cells. Other studies have demonstrated that the inhibitory growth effects of IL-32 were partly dependent on lymphocytes, dendritic cells and other cytokines $(46,49)$.

These results indicated contradictory functions of IL-32 on tumour growth. It is possible that alternative splicing of IL-32 leads to discrepancies in functional studies. Heinhuis et al (23) revealed that 293 cells overexpressing IL-32 $\beta$ or IL-32 $\gamma$ underwent cell death, while human mammalian cell lines expressing high levels of IL-32 $\alpha$ did not. These opposing functions have also been reported in the alternative splice variants of IL-6 and IL-24 $(50,51)$. One function of IL-6 is to promote cell proliferation, but an alternatively spliced IL-6 variant can counteract this effect. Similarly, IL-24-induced cell death can be blocked by an IL-24 splice variant.

The motogenic properties of IL-32. IL-32 has also been demonstrated to influence tumour cell motility, a critical factor in tumour cell invasion and metastasis. In gastric cancer, Tsai et al (13) established stable IL-32-expressing cell sublines and revealed that all IL-32-overexpressing cells had protrusions at their leading edges with elongated, spindle-like morphology compared with that of the control cells. In addition to these morphological characteristics, IL-32-overexpressing cells displayed significantly higher invasive, metastatic and wound healing capacities compared with those of control cells. Similar observations were also repeatedly obtained in doxycycline-induced IL-32-overexpressing cells. This study also revealed that the underlying mechanism of IL-32-triggered cell invasion was an increase in the expression levels of IL-8, vascular endothelial growth factor (VEGF), matrix metalloproteinase (MMP)2 and MMP9, and activation of protein kinase $\mathrm{B}(\mathrm{Akt}), \beta$-catenin and hypoxia inducible factor $1 \alpha$ (HIF-1 $\alpha)(13)$. These findings are in line with those of previous studies, which revealed that the IL-32-acquired invasive and migration phenotype of lung cancer was mediated through the co-expression of IL-8 and VEGF (40).

The involvement of IL-32 in tumour migration and invasion has also been demonstrated in breast cancer (15). Previous study has reported that overexpression of IL-32 $\beta$ increased tumour cell migration and invasion in human breast cancer cells. By contrast, knockdown of IL-32 negated these effects. Additionally, the motogenic effect of IL-32 was stimulated by IL-32 $\beta$-induced VEGF (15). In addition, Guenin et al (52) demonstrated that IL-32 induced the migration of head and neck squamous cell carcinoma cells by regulating the expression of Snail. In HCC, IL-32 $\alpha$-expressing tumour cells invaded blood vessels, which may suggest an association between IL-32 $\alpha$ expression and tumour metastasis (9). More recently, studies have revealed a motogenic effect of IL-32 in osteosarcoma and melanoma $(53,54)$. 


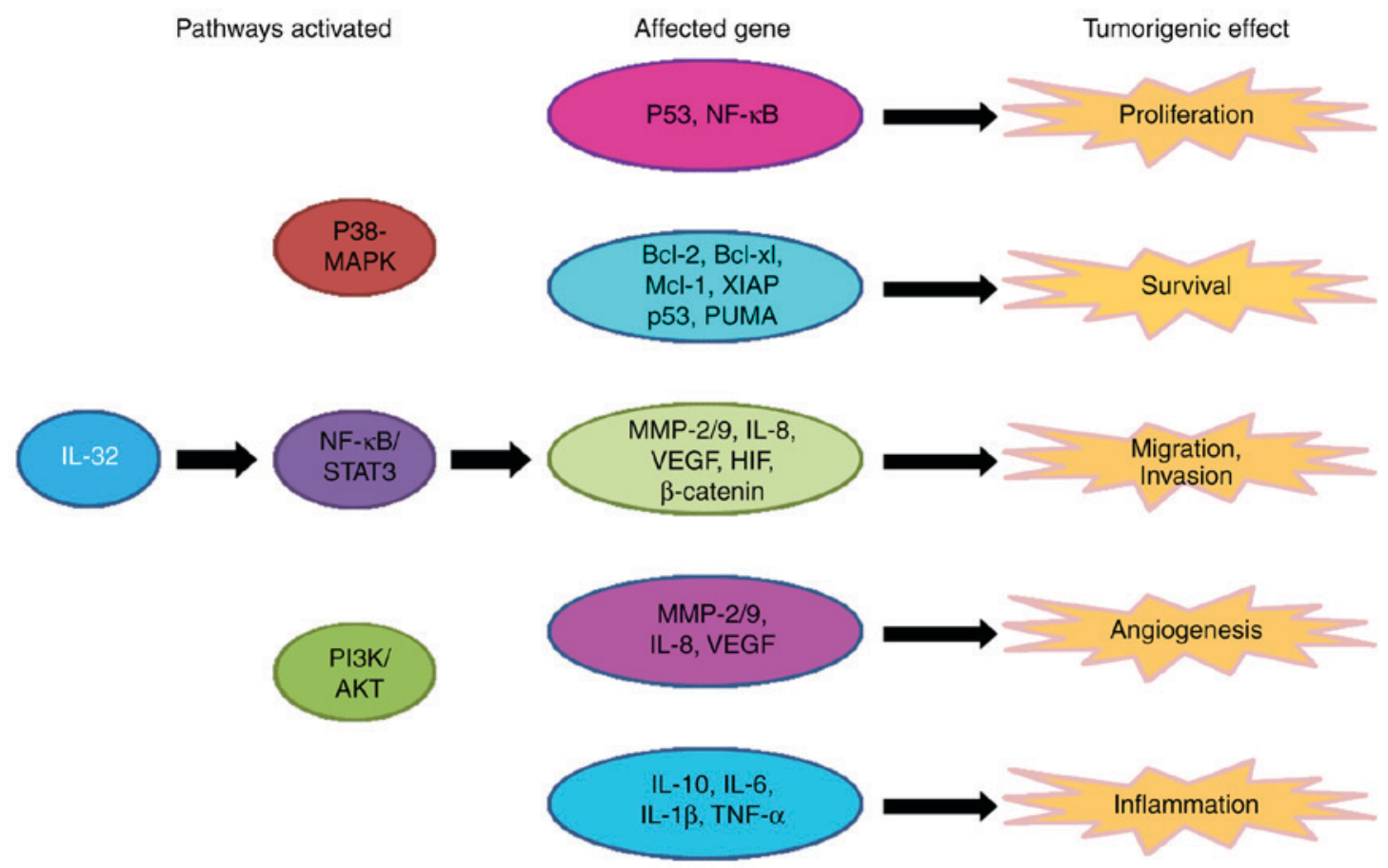

Figure 1. The role and molecular pathway of IL-32 in cancer. IL-32 activates 3 pathways: The P38-MAPK, NF-kB/STAT-3 and PI3K/Akt pathways. The activation of these pathways modifies the expression of several genes that affect cell proliferation, survival, migration and invasion, and carcinogenic angiogenesis

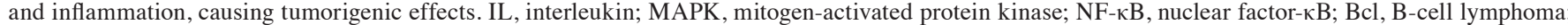
Mcl-1, induced myeloid leukemia cell differentiation protein 1; XIAP, x-linked inhibitor of apoptosis; PUMA, p53 upregulated modulator of apoptosis; MMP, matrix metalloproteinase; VEGF, vascular endothelial growth factor; STAT, signal transducer and activator of transcription; PI3K, phosphoinositide 3-kinase; Akt, protein kinase B; HIF, hypoxia-inducible factor; TNF, tumour necrosis factor.

Taken together, these results suggested that IL-32 expression increases the migration and invasion capacities of tumour cells. By contrast, a recent study revealed that overexpression of a different IL-32 isoform (IL-320) in colon cells displayed a decrease in their invasiveness and in their oncogenic capabilities (55). Therefore, the detrimental role of IL-32 in multiple types of cancer may be clinically relevant.

The angiogenic properties of $I L-32$. In human pulmonary arterial hypertension and glioblastoma multiforme, hyper-proliferative endothelial cells (ECs) revealed a significant increase in IL-32 expression (56). Furthermore, suppression of IL-32 negatively affected the proliferation of ECs and downregulated expression levels of nitric oxide, IL-8 and MMP-9 in adult and neonatal ECs (56). Functional studies that used co-culture-based angiogenesis assays revealed an IL-32 increased tube formation in a dose-dependent manner. By contrast, an $\alpha \mathrm{V} \beta 3$ inhibitor attenuated this response and reduced the expression of IL-32 $\gamma$-induced IL-8. These studies demonstrated that IL-32 promotes angiogenesis partially through the integrin $\alpha \mathrm{V} \beta 3$. The direct association between IL-32 and tumour angiogenesis remains undetermined, and associated studies are limited. In gastric cancer, IL-32 can induce the expression of IL-8, VEGF, MMP2 and MMP9 (13). Notably, IL-8 is a particularly well-established potent promoter of angiogenesis. IL-32 may indirectly promote tumour angiogenesis via inducing other cytokines and growth factors.

It may be beneficial to evaluate the angiogenic activity of IL-32 in human cancer, as angiogenesis serves a crucial role in the pathogenesis and progression of cancer. In summary, IL-32 is involved in multiple aspects of cancer development, including growth, migration and angiogenesis (Fig. 1).

\section{The mechanisms of IL-32 in cancer}

To directly investigate the mechanisms of IL-32-mediated tumour growth and metastasis, various human tumour cell lines have been transfected with the IL-32 gene. The effect of IL-32-transfection on tumour inhibition and promotion depends on the tumour cell type. For example, IL-32 $\beta$-transfected breast cancer cells demonstrated stronger migration and invasion abilities than those of control tumour cells, and this process was mainly dependent on the IL-32 $\beta$-VEGF-STAT3 pathway (15). In addition, Tsai et al (13) revealed that ectopic expression of IL-32 in gastric cancer cell lines increased metastatic potential via increased activity of Akt, $\beta$-catenin and HIF-1 $\alpha$. Tumour cells were also used to monitor cell survival and tumour development following transfection with IL-32-specific small interfering RNA. In pancreatic cancer, IL-32 suppression markedly stimulated apoptosis by downregulating anti-apoptotic proteins. This finding was confirmed in human HCC (9).

However, in chronic myeloid leukaemia, IL-32-transfected cells were more susceptible to NK cell-mediated killing than control tumour cells (47). In another study, IL-32 overexpression inhibited cancer development in cervical cancer cells compared with mock-control cells (41). Additionally, overexpression of IL-32 in colon and prostate cancer cell lines inhibited tumour growth. It was hypothesised that IL-32 may 
promote TNF- $\alpha$-induced cell growth inhibition or induce death through the TNFR1 signalling pathway $(14,48)$. Notably, in vivo tumour growth was significantly slower in mice with IL-32 $\gamma$-transfected HCT116 colon cancer cells compared with control cells $(45,46)$. Additionally, the anticancer effect of IL-32 was associated with the increased infiltration of CD8+ T cells, lymphocytes and NK cells.

These results illustrated the discrepant effects of IL-32 in cancer. The inconsistent observations among these results might originate from malignancy-specific variations in downstream pathways of IL-32. IL-32 is associated with various pathways, including the nuclear factor- $\kappa \mathrm{B}$ and $\mathrm{p} 38$ mitogen-activated protein kinase pathways (18), extracellular signal-regulated kinase-1/2 and phosphoinositide 3-kinase/Akt pathways (57), a caspase-1-mediated pathway that can be synchronized with nucleotide-binding oligomerization domain-containing protein 1 and 2 ligands (58), and a caspase-3-dependent pathway (59), depending on the tumour type and tumour microenvironment (Fig. 1). Determining the modulatory effects of IL-32 on pathways is challenging, particularly since it may be affected by variations in the tumour microenvironment.

\section{The regulation of IL-32 in cancer}

Aberrant expression levels of IL-32 serve an important role in cancer, and therefore represent a potential therapeutic target. The mechanisms of IL-32 expression regulation in cancer have been studied by several groups. In epithelial cell-derived thyroid carcinoma (TC) (60), Plantinga et al (60) revealed that patients with TC have an overrepresentation of the ancient $\mathrm{T}$ allele, and lipopolysaccharide-induced expression of IL-32 was higher in cells homozygous for the ancient $\mathrm{T}$ allele than in cells without this allele. These results clearly reveal that genetic variations of IL-32 can lead to an increase in IL-32 gene expression. In addition, the transcription factor Oct4 also increased IL-32 expression at the mRNA and protein levels in colorectal cancer cells (61). It has been reported that microRNA-205 induces an increase in IL-32 mRNA and protein expression levels (62). These results are consistent with those of another study that revealed that the inhibition of miR-23b-3p induces a reduction in IL-32 expression in renal cancer (63). In summary, IL-32 expression levels appear to correlate with genetic factors, including genetic variations, transcription factor and microRNAs.

Using immunostaining and reverse transcription-polymerase quantitative chain reaction, Suga et al (16) revealed that IL-32 was more predominantly expressed in skin lesions of patients with cutaneous T-cell lymphoma than in normal skin, suggesting that hypoxia may contribute to the overexpression of IL-32. It has been confirmed that hypoxia induces IL-32 in human breast cancer cells $(15,64)$; hypoxic challenges led to a time-dependent increase in the expression of IL-32 in breast cancer cells. A recent study reported that IL-32 was induced by hypoxia and secreted from multiple myeloma cells in extracellular vesicles (65). Furthermore, IL-32 $\beta$ expression levels were upregulated by a hypoxia mimetic chemical, $\mathrm{CoCl}_{2}$. These results demonstrated that hypoxia enhances the expression of IL-32, which may contribute to the progression and metastasis of human cancer. Additionally, acidic conditions also contribute to increases in IL-32 expression (66). Identification of the mechanisms underlying IL-32 modulation are required prior to this novel cytokine being used as a target in human cancer treatments.

\section{Conclusion and future directions}

Inflammatory microenvironments serve a critical role in tumorigenesis, imposing significant challenges in the design of effective cancer therapy. Among growth factors and cytokines, IL-32 may be an additional mediator of human cancer development and therefore may provide a novel therapeutic strategy. Understanding the biological activity of IL-32 in cancer progression requires a comprehensive analysis of the results obtained from clinical studies, cell cultures and animal models. Nevertheless, further investigations are required to elucidate the paradoxical role of IL-32 in cancer, which appears to be due in part to IL-32 isoforms and variations in the tumour microenvironment. It is apparent that various mechanisms are involved in IL-32 actions, including direct effects on tumour cell proliferation, angiogenesis and metastasis, and indirect effects via inflammatory cells, including neutrophils and macrophages. The mechanisms of the antitumour effect of IL-32 must be identified, and tumour-stimulating actions must be neutralised. Identifying the optimal IL-32 isoform to function in a particular disease may indicate new directions for the development of antitumor strategies.

\section{Acknowledgements}

Not applicable.

\section{Funding}

The present study was supported by the National Natural Science Foundation of China (grant nos. 91429302, 81201868 and 81560030).

\section{Availability of data and materials}

Not applicable.

\section{Authors' contributions}

ZC and HY designed and conceived the study. DH, XH, EZ, QC, RX, XL, FZ and ZC provided advice and assistance. HY wrote the manuscript. All authors have contributed to and approved the final manuscript.

\section{Ethics approval and consent to participate}

Not applicable.

\section{Consent for publication}

Not applicable.

\section{Competing interests}

The authors declare that they have no competing interests. 


\section{References}

1. Grivennikov SI, Greten FR and Karin M: Immunity, inflammation, and cancer. Cell 140: 883-899, 2010.

2. Colotta F, Allavena P, Sica A, Garlanda C and Mantovani A: Cancer-related inflammation, the seventh hallmark of cancer: Links to genetic instability. Carcinogenesis 30: 1073-1081, 2009.

3. Hanahan D and Weinberg R: Hallmarks of cancer: The next generation. Cell 144: 646-674, 2011

4. Wang L, Liu Z, Balivada S, Shrestha T, Bossmann S, Pyle M, Pappan L, Shi J and Troyer D: Interleukin-1 $\beta$ and transforming growth factor- $\beta$ cooperate to induce neurosphere formation and increase tumorigenicity of adherent LN-229 glioma cells. Stem Cell Res Ther 3: 5, 2012.

5. Lin L, Liu A, Peng Z, Lin HJ, Li PK, Li C and Lin J: STAT3 is necessary for proliferation and survival in colon cancer-initiating cells. Cancer Res 71: 7226-7237, 2011

6. Srivastava SK, Bhardwaj A, Arora S, Tyagi N, Singh AP, Carter JE, Scammell JG, Fodstad $\varnothing$ and Singh S: Interleukin-8 is a key mediator of FKBP51-induced melanoma growth, angiogenesis and metastasis. Br J Cancer 112: 1772-1781, 2015

7. Tao H, Lu L, Xia Y, Dai F, Wang Y, Bao Y, Lundy SK, Ito F, Pan Q, Zhang X, et al: Antitumor effector B cells directly kill tumor cells via the Fas/FasL pathway and are regulated by IL-10. Eur J Immunol 45: 999-1009, 2015.

8. Yoshimoto T, Chiba Y, Furusawa J, Xu M, Tsunoda R, Higuchi K and Mizoguchi I: Potential clinical application of interleukin-27 as an antitumor agent. Cancer Sci 106: 1103-1110, 2015

9. Kang YH, Park MY, Yoon DY, Han SR, Lee CI, Ji NY, Myung PK, Lee HG, Kim JW, Yeom YI, et al: Dysregulation of overexpressed IL-32 $\alpha$ in hepatocellular carcinoma suppresses cell growth and induces apoptosis through inactivation of NF- $\mathrm{KB}$ and Bcl-2. Cancer Lett 318: 226-233, 2012.

10. Nishida A, Andoh A, Inatomi O and Fujiyama Y: Interleukin-32 expression in the pancreas. J Biol Chem 284: 17868-17876, 2009.

11. Yousif NG, Al-Amran FG, Hadi N, Lee J and Adrienne J: Expression of IL-32 modulates NF- $\mathrm{KB}$ and p38 MAP kinase pathways in human esophageal cancer. Cytokine 61: 223-227, 2013.

12. Zeng Q, Li S, Zhou Y, Ou W, Cai X, Zhang L, Huang W, Huang L and Wang Q: Interleukin-32 contributes to invasion and metastasis of primary lung adenocarcinoma via NF-kappaB induced matrix metalloproteinases 2 and 9 expression. Cytokine 65: 24-32, 2014

13. Tsai CY, Wang CS, Tsai MM, Chi HC, Cheng WL, Tseng YH Chen CY, Lin CD, Wu JI, Wang LH and Lin KH: Interleukin-32 increases human gastric cancer cell invasion associated with tumor progression and metastasis. Clin Cancer Res 20: 2276-2288, 2014.

14. Yun HM, Park KR, Kim EC, Han SB, Yoon DY and Hong JT: IL-32 $\alpha$ suppresses colorectal cancer development via TNFR1-mediated death signaling. Oncotarget 6: 9061-9072, 2015.

15. Park JS, Choi SY, Lee JH, Lee M, Nam ES, Jeong AL, Lee S, Han S, Lee MS, Lim JS, et al: Interleukin-32 $\beta$ stimulates migration of MDA-MB-231 and MCF-7cells via the VEGF-STAT3 signaling pathway. Cell Oncol (Dordr) 36: 493-503, 2013.

16. Suga H, Sugaya M, Miyagaki T, Kawaguchi M, Fujita H, Asano Y, Tada Y, Kadono T and Sato S: The role of IL-32 in cutaneous T-cell lymphoma. J Invest Dermatol 134: 1428-1435, 2014.

17. Dahl CA, Schall RP, He HL and Cairns JS: Identification of a novel gene expressed in activated natural killer cells and T cells. J Immunol 148: 597-603, 1992.

18. Kim SH, Han SY, Azam T, Yoon DY and Dinarello CA: Interleukin-32: A cytokine and inducer of TNFalpha. Immunity 22: 131-142, 2005.

19. Kang JW, Park YS, Lee DH, Kim MS, Bak Y, Ham SY, Park SH, Kim H, Ahn JH, Hong JT and Yoon DY: Interaction network mapping among IL-32 isoforms. Biochimie 101: 248-251, 2014.

20. Goda C, Kanaji T, Kanaji S, Tanaka G, Arima K, Ohno S and Izuhara K: Involvement of IL-32 in activation-induced cell death in T cells. Int Immunol 18: 233-240, 2006.

21. Choi JD, Bae SY, Hong JW, Azam T, Dinarello CA, Her E, Choi WS, Kim BK, Lee CK, Yoon DY, et al: Identification of the most active interleukin-32 isoform. Immunology 126: 535-542, 2009.

22. Heinhuis B, Koenders MI, van de Loo FA, Netea MG, van den Berg WB and Joosten LA: Inflammation-dependent secretion and splicing of IL-32 \{gamma\} in rheumatoid arthritis. Proc Natl Acad Sci USA 108: 4962-4967, 2011.
23. Heinhuis B, Plantinga TS, Semango G, Küsters B, Netea MG, Dinarello CA, Smit JWA, Netea-Maier RT and Joosten LAB: Alternatively spliced isoforms of IL-32 differentially influence cell death pathways in cancer cell lines. Carcinogenesis 37 : 197-205, 2016.

24. Jung MY, Son MH, Kim SH, Cho D and Kim TS: IL-32gamma induces the maturation of dendritic cells with Th1- and Th17-polarizing ability through enhanced IL-12 and IL-6 production. J Immunol 186: 6848-6859, 2011

25. Yun HM, Kim JA, Hwang CJ, Jin P, Baek MK, Lee JM, Hong JE, Lee SM, Han SB, Oh KW, et al: Neuroinflammatory and amyloidogenic activities of IL-32 $\beta$ in Alzheimer's disease. Mol Neurobiol 52: 341-352, 2014.

26. Hong JT, Son DJ, Lee CK, Yoon DY, Lee DH and Park MH: Interleukin 32, Inflammation and Cancer. Pharmacol Ther 174: 127-137, 2017.

27. Kang JW, Park YS, Lee DH, Kim JH, Kim MS, Bak Y, Hong J and Yoon DY: Intracellular interaction of interleukin (IL)-32 $\alpha$ with protein kinase $\mathrm{C} \varepsilon(\mathrm{PKC} \varepsilon)$ and STAT3 protein augments IL-6 production in THP-1 promonocytic cells. J Biol Chem 287: 35556-35564, 2012.

28. Park YS, Kang JW, Lee DH, Kim MS, Bak Y, Yang Y, Lee HG, Hong $\mathrm{J}$ and Yoon DY: Interleukin-32 $\alpha$ downregulates the activity of the B-cell CLL/lymphoma 6 protein by inhibiting protein kinase CE-dependent SUMO-2 modification. Oncotarget 5: 8765-8777, 2014

29. Bak Y, Kang JW, Kim MS, Park YS, Kwon T, Kim S, Hong J and Yoon DY: IL-32 $\theta$ downregulates CCL5 expression through its interaction with PKC $\delta$ and STAT3. Cell Signal 26: 3007-3015, 2014.

30. Kang JW, Park YS, Lee DH, Kim MS, Bak Y, Park SH, Ham SY, Yang Y, Hong JT and Yoon DY: Interleukin-32 $\delta$ interacts with IL-32 $\beta$ and inhibits IL-32 $\beta$-mediated IL-10 production. FEBS Lett: Oct 25, 2013 (Epub ahead of print).

31. Hasegawa H, Thomas HJ, Schooley K and Born TL: Native IL-32 is released from intestinal epithelial cells via a non-classical secretory pathway as a membrane-associated protein. Cytokine 53: 74-83, 2011.

32. Novick D, Rubinstein M, Azam T, Rabinkov A, Dinarello CA and Kim SH: Proteinase 3 is an IL-32 binding protein. Proc Natl Acad Sci USA 103: 3316-3321, 2006.

33. Heinhuis B, Koenders MI, van den Berg WB, Netea MG, Dinarello CA and Joosten LA: Interleukin 32 (IL-32) contains a typical $\alpha$-helix bundle structure that resembles focal adhesion targeting region of focal adhesion kinase-1. J Biol Chem 287: 5733-5743, 2012

34. Netea MG, Lewis EC, Azam T, Joosten LA, Jaekal J, Bae SY, Dinarello CA and Kim SH: Interleukin-32 induces the differentiation of monocytes into macrophage-like cells. Proc Natl Acad Sci USA 105: 3515-3520, 2008

35. Ohmatsu H, Humme D, Gonzalez J, Gulati N, Möbs M, Sterry W and Krueger JG: IL-32 induces indoleamine 2,3-dioxygenase ${ }^{+} \mathrm{CD}_{1 \mathrm{c}^{+}}$dendritic cells and indoleamine 2,3-dioxygenase ${ }^{+} \mathrm{CD} 163^{+}$macrophages: Relevance to mycosis fungoides progression. OncoImmunology 6: e1181237, 2016.

36. Joosten LA, Netea MG, Kim SH, Yoon DY, Oppers-Walgreen B, Radstake TR, Barrera P, van de Loo FA, Dinarello CA and van den Berg WB: IL-32, a proinflammatory cytokine in rheumatoid arthritis. Proc Natl Acad Sci USA 103: 3298-3303, 2006.

37. Calabrese F, Baraldo S, Bazzan E, Lunardi F, Rea F, Maestrelli P, Turato G, Lokar-Oliani K, Papi A, Zuin R, et al: IL-32, a novel proinflammatory cytokine in chronic obstructive pulmonary disease. Am J Respir Crit Care Med 178: 894-901, 2008.

38. Choi J, Bae S, Hong J, Ryoo S, Jhun H, Hong K, Yoon D, Lee S, Her E, Choi W, et al: Paradoxical effects of constitutive human IL-32\{gamma\} in transgenic mice during experimental colitis. Proc Natl Acad Sci USA 107: 21082-21086, 2010.

39. Bai X, Kim SH, Azam T, McGibney MT, Huang H, Dinarello CA and Chan ED: IL-32 is a host protective cytokine against Mycobacterium tuberculosis in differentiated THP-1 human macrophages. J Immunol 184: 3830-3840, 2010.

40. Sorrentino C and Di Carlo E: Expression of IL-32 in human lung cancer is related to the histotype and metastatic phenotype. Am J Respir Crit Care Med 180: 769-779, 2009.

41. Lee S, Kim JH, Kim H, Kang JW, Kim SH, Yang Y, Kim J, Park J, Park S, Hong J and Yoon DY: Activation of the interleukin-32 pro-inflammatory pathway in response to human papillomavirus infection and over-expressionof interleukin-32 controls the expression of the humanpapillomavirus oncogene. Immunology 132: 410-420, 2011. 
42. Marcondes AM, Mhyre AJ, Stirewalt DL, Kim SH, Dinarello CA and Deeg HJ: Dysregulation of IL-32 in myelodysplastic syndrome and chronic myelomonocytic leukemia modulates apoptosis and impairs NK function. Proc Natl Acad Sci USA 105: 2865-2870, 2008.

43. Wang S, Chen F and Tang L: IL-32 promotes breast cancer cell growth and invasiveness. Oncol Lett 9: 305-307, 2015.

44. Lin X, Yang L, Wang G, Zi F, Yan H, Guo X, Chen J, Chen Q, Huang $\mathrm{X}, \mathrm{Li} \mathrm{Y}$, et al: Interleukin-32 $\alpha$ promotes the proliferation of multiple myeloma cells by inducing production of IL- 6 in bone marrow stromal cells. Oncotarget 8: 92841-92854, 2017.

45. Oh JH, Cho MC, Kim JH, Lee SY, Kim HJ, Park ES, Ban JO, Kang JW, Lee DH, Shim JH, et al: IL-32 $\gamma$ inhibits cancer cell growth through inactivation of NF- $\mathrm{KB}$ and STAT3 signals. Oncogene 30: 3345-3359, 2011.

46. Yun HM, Oh JH, Shim JH, Ban JO, Park KR, Kim JH, Lee DH, Kang JW, Park YH, Yu D, et al: Antitumor activity of IL-32 $\beta$ through the activation of lymphocytes, and the inactivation of NF- $\kappa \mathrm{B}$ and STAT3 signals. Cell Death Dis 4: e640, 2013.

47. Cheon S, Lee JH, Park S, Bang SI, Lee WJ, Yoon DY, Yoon SS Kim T, Min H, Cho BJ, et al: Overexpression of IL-32alpha increases natural killer cell-mediated killing through up-regulation of Fas and UL16-binding protein 2 (ULBP2) expression in human chronic myeloid leukemia cells. J Biol Chem 286: 12049-12055, 2011.

48. Park ES, Yoo JM, Yoo HS, Yoon DY, Yun YP and Hong J: IL-32 $\gamma$ enhances TNF- $\alpha$-induced cell death in colon cancer. Mo Carcinog 53 (Suppl 1): E23-E35, 2014.

49. Qu Y, Taylor JL, Bose A and Storkus WJ: Therapeutic effectiveness of intratumorally delivered dendritic cells engineered to express the pro-inflammatory cytokine, interleukin (IL)-32. Cancer Gene Ther 18: 663-673, 2011.

50. Alberti L, Bachelot T, Duc A, Biota C and Blay JY: A spliced isoform of interleukin $6 \mathrm{mRNA}$ produced by renal cell carcinoma encodes for an interleukin 6 inhibitor. Cancer Res 65: 2-5, 2005

51. Sahoo A, Jung YM, Kwon HK, Yi HJ, Lee S, Chang S, Park ZY, Hwang KC and Im SH: A novel splicing variant of mouse interleukin (IL)-24 antagonizes IL-24-induced apoptosis. J Biol Chem 283: 28860-28872, 2008.

52. Guenin S, Mouallif M, Hubert P, Jacobs N, Krusy N, Duray A, Ennaji MM, Saussez S and Delvenne P: Interleukin-32 expression is associated with a poorer prognosis in head and neck squamous cell carcinoma. Mol Carcinog 53: 667-673, 2014.

53. Lee J, Kim KE, Cheon S, Song JH, Houh Y, Kim TS, Gil M, Lee KJ, Kim S, Kim D, et al: Interleukin-32 $\alpha$ induces migration of human melanoma cells through downregulation of E-cadherin. Oncotarget 7: 65825-65836, 2016.

54. Zhou Y, Hu Z, Li N and Jiang R: Interleukin-32 stimulates osteosarcoma cell invasion and motility via AKT pathway-mediated MMP-13 expression. Int J Mol Med 35: 1729-1733, 2015.
55. Bak Y, Kwon T, Bak IS, Hong J, Yu DY and Yoon DY: IL-320 inhibits stemness and epithelial-mesenchymal transition of cancer stem cells via the STAT3 pathway in colon cancer. Oncotarget 7: 7307-7317, 2016.

56. Nold-Petry CA, Rudloff I, Baumer Y, Ruvo M, Marasco D, Botti P, Farkas L, Cho SX, Zepp JA, Azam T, et al: IL-32 promotes angiogenesis. J Immunol 192: 589-602, 2014.

57. Mabilleau G and Sabokbar A: Interleukin-32 promotes osteoclast differentiation but not osteoclast activation. PLoS One 4: e4173, 2009.

58. Netea MG, Azam T, Ferwerda G, Girardin SE, Walsh M, Park JS, Abraham E, Kim JM, Yoon DY, Dinarello CA and Kim SH: IL-32 synergizes with nucleotide oligomerization domain (NOD) 1 and NOD2 ligands for IL-1beta and IL-6 production through a caspase 1-dependent mechanism. Proc Natl Acad Sci USA 102: 16309-16314, 2005.

59. Joosten LA, Heinhuis B, Netea MG and Dinarello CA: Novel insights into the biology of interleukin-32. Cell Mol Life Sci 70: 3883-3892, 2013

60. Plantinga TS, Costantini I, Heinhuis B, Huijbers A, Semango G, Kusters B, Netea MG, Hermus AR, Smit JW, Dinarello CA, et al: A promoter polymorphism in human interleukin-32 modulates its expression and influences the risk and the outcome of epithelial cell-derived thyroid carcinoma. Carcinogenesis 34: 1529-1535, 2013.

61. Chang CJ, Chien Y, Lu KH, Chang SC, Chou YC, Huang CS, Chang $\mathrm{CH}$, Chen KH, Chang YL, Tseng LM, et al: Oct4-related cytokine effects regulate tumorigenic properties of colorectal cancer cells. Biochem Biophys Res Commun 415: 245-251, 2011.

62. Majid S, Dar AA, Saini S, Yamamura S, Hirata H, Tanaka Y, Deng G and Dahiya R: MicroRNA-205-directed transcriptional activation of tumor suppressor genes in prostate cancer. Cancer 116: 5637-5649, 2010.

63. Zaman MS, Thamminana S, Shahryari V, Chiyomaru T, Deng G, Saini S, Majid S, Fukuhara S, Chang I, Arora S, et al: Inhibition of PTEN gene expression by oncogenic miR-23b-3p in renal cancer. PLoS One 7: e50203, 2012.

64. Park JS, Lee S, Jeong AL, Han S, Ka HI, Lim JS, Lee MS, Yoon DY, Lee JH and Yang Y: Hypoxia-induced IL-32 $\beta$ increases glycolysis in breast cancer cells. Cancer Lett 356: 800-808, 2015

65. Zahoor M, Westhrin M, Aass KR, Moen SH, Misund K, Psonka-Antonczyk KM, Giliberto M, Buene G, Sundan A, Waage A, et al: Hypoxia promotes IL-32 expression in myeloma cells, and high expression is associated with poor survival and bone loss. Blood Adv 1: 2656-2666, 2017.

66. Fukamachi T, Ikeda S, Wang X, Saito H, Tagawa $M$ and Kobayashi $\mathrm{H}$ : Gene expressions for signal transduction under acidic conditions. Genes (Basel) 4: 65-85, 2013. 